\title{
ORIGINAL
}

\section{Lipid and Fatty Acid Compositions of the Cytoplasmic and Thylakoid Membranes from the Thermophilic Cyanobacterium Synechococcus elongatus}

\author{
Hisaaki YAGI, Sachio MIYAIRI, Toro NAKAHARA, Toshiaki ICHIMURA, \\ Ikuo MATSUI, and Koichi HONDA \\ National Chemical Laboratory for Industry \\ (1-1 Higashi, Tsukuba-shi, Ibaraki-ken, =305)
}

\begin{abstract}
The cytoplasmic membranes (CM) and thylakoid membranes (TM) were isolated from the thermophilic cyanobacterium Synechococcus elongatus. These membranes contained similar rates of polar lipid classes; monogalactosyldiacylglycerol (MGDG) (ca.58\%), digalactosyldiacylglycerol (DGDG) (ca.16\%), sulfoquinovosyldiacylglycerol (SQDG) (ca.11\%) and phosphatidylglycerol (PG) (ca. $8 \%$ ). In either membranes, about $50 \%$ of the total lipid consisted of pigments, of which about two thirds was chlorophyll-a in TM, while in CM chlorophyll-a was at a trace amount. The remains of the pigments were supposed to be carotenoids in either membranes. Of the fatty acids of the lipids in either membranes, palmitic acid $(16: 0)$ comprised more than $50 \%$, oleic acid $(18: 1)$ about $20 \%$, cis-9-hexadecenoic acid (palmitoleic acid; $16: 1$ ) about $15 \%$, stearic acid (18:0) about $10 \%$. Comparing with mesophilic cyanobacteria, the Synechococcus membranes contained more pigments, less PG and more saturated fatty acids, and showed simpler profiles of fatty acid compositions.
\end{abstract}

\section{Introduction}

The cyanobacteria (blue-green algae) are Gram-negative bacteria, in which the cell envelope is composed of outer and inner (cytoplasmic) membranes with a peptidoglycan layer in between. In the cytoplasm are the TM, which are the sites of the primary process of photosynthesis. Higher plants and algae have abundant glycolipids.

Several studies of lipids in cyanobacteria have focussed on the roles of lipids in thermo-adaptation and in photosynthetic functions. It was shown with the cells of the thermophilic cyanobacterium Mastigocladus laminosus that the content of unsaturated fatty acids increased as lowering of growth temperature ${ }^{1)}$. Growth temperature also affected on the chain length of fatty acids and lipids class levels ${ }^{1)}$. And recent

\footnotetext{
Corresponding author : Sachio MIYAIRI
}

study suggested that MGDG, PG and SQDG contributed energy transfer in the thylakoids, while DGDG was less effective on the reaction ${ }^{2)}$. Murata et al. isolated CM and TM from a mesophilic cyanobacterium Anacystis nidulans and analyzed their lipid and fatty acid compositions ${ }^{3), 4)}$. The reports show that the two membrane species have some different lipid composition, but have almost identical fatty acid composition.

We have studied on the mechanism of light energy conversion in the TM of the thermophilic cyanobacterium Synechococcus elongatus ${ }^{5)}$. We aim to clear lipid and fatty acid compositions in relation to the functions of the cyanobacterial membranes.

The present paper reports isolation of the $\mathrm{CM}$ and TM from the cells of $S$. elongatus and analysis of lipid and fatty acid compositions of the membranes. 


\section{Materials and Methods}

S. elongatus was cultivated at $52^{\circ} \mathrm{C}$ for $3 \mathrm{~d}$ under white light with continuous air bubbling containing $5 \% \mathrm{CO}_{2}{ }^{6}$. Preparation of $\mathrm{CM}$ and TM was performed according to the previous method ${ }^{4}$ with some modifications. Concentrations of EDTA and lysozyme for the lysozyme treatment of the cells were 5 $\mathrm{mM}$ and $0.2 \%$, respectively, and the cells were passed twice through a French pressure at $160 \mathrm{MPa}$. Two membrane fractions obtained as an upper and a lower bands by floatation centrifugation were subjected to the following analyses.

Light dependent $\mathrm{O}_{2}$ evolution was measured with a Clark-type electrode at $40^{\circ} \mathrm{C}$ in $50 \mathrm{mM}$ MES-NaOH buffer ( $\mathrm{pH}$ 5.5) containing $0.5 \mathrm{M}$ sucrose, $20 \mathrm{mM}$ sodium chloride, $10 \mathrm{mM}$ magnesium chloride and $1 \mathrm{mM}$ potassium hexacyanoferrate (III) as an electron acceptor ${ }^{5)}$.

Lipids were extracted from the membranes according to the method of Bligh and Dyer ${ }^{7)}$ with homogenation at 10,000 rpm for $1 \mathrm{~min}$ and separated by TLC on silica gel using chloroform/methanol/ammonia (28\%) (13: $7: 1$ by volume) as the developing solvent ${ }^{4}$. Lipids were visualized with iodine vapor and $13 \% \mathrm{H}_{2} \mathrm{SO}_{4}$ solution containing $3 \% \mathrm{CuSO}_{4}$, and spot densities were measured with a Shimadzu Densitometer CS-910 with a zig-zag scanning mode. Glycolipids were visualyzed by naphthol spray reagent ${ }^{8}$ and phospholipids by Dittmer stain (spray reagent) ${ }^{9)}$. Chlorophyll-a extracted from the membranes with $80 \%$ acetone was determined from the absorbance at $663 \mathrm{~nm}^{10)}$. Carotenoids content was calculated by reducing the amount of chlorophyll-a from pigments content determined by TLC. Lipid identification was also achieved by co-chromatography with lipid standards. The lipids extracted from the membranes were dried and saponified with methanolic $\mathrm{NaOH}$, and the preparation of methyl esters was carried out with methanolic-boron trifluoride-methanol solution after Metcalfe and Schmitz ${ }^{11)}$. Fatty acid analysis was performed by gas-liquid chro- matography with a glass capillary column (CPS-2, $0.25 \mathrm{~mm} \times 25 \mathrm{~m}$, Quadrex Inc.) using a temperature programming condition (150 to $200^{\circ} \mathrm{C}$ at a $2^{\circ} \mathrm{C} / \mathrm{min}$ increment).

\section{Results and Discussion}

Absorption spectra of the two membrane fractions obtained from $S$. elongatus are shown in Fig.-1. The absorption spectrum of the upper fraction (CM), which is similar to that of the CM from $A$. nidulans, indicates that the fraction contained abundant carotenoids and a small amount of chlorophyll-a. The spectrum of the lower fraction, which was similar to that of TM from $A$. nidulans, shows that the fraction contained abundant chlorophyll-a, phycocyanin and a little carotenoids. The minor peak of chlorophyll-a in the upper fraction was at $674 \mathrm{~nm}$ which was shorter than $678 \mathrm{~nm}$ of the chlorophyll-a peak in the lower fraction. The lower fraction exhibited light dependent $\mathrm{O}_{2}$ evolving activity of $52 \mu \mathrm{mol} / \mathrm{mg} \mathrm{chl} / \mathrm{h}$, while the upper fraction did not show any $\mathrm{O}_{2}$ evolving activity. These results show that the upper and lower fractions consisted of $\mathrm{CM}$ and TM, respectively. And these membranes were subjected to the analyses of lipid classes and fatty acid compositions.

The lipid compositions of the membranes

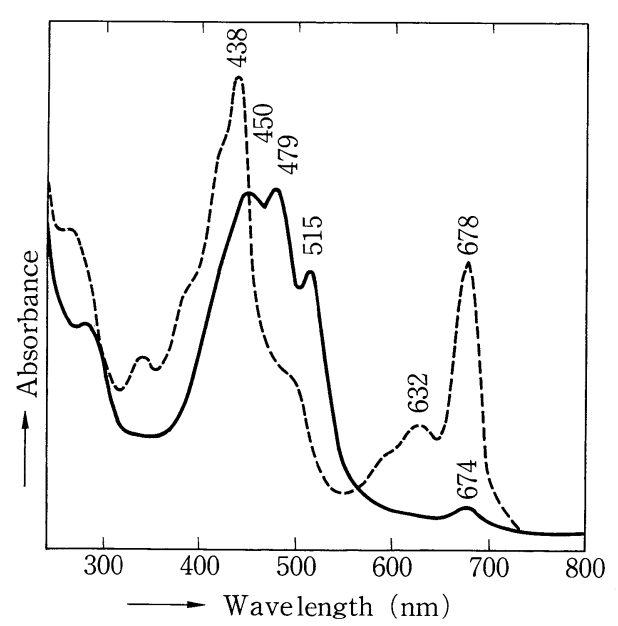

Fig.-1 Absorption spectra of the upper fraction (CM) (-) and the lower fraction (TM) $(\cdots)$ at $20^{\circ} \mathrm{C}$. Absorbance is expressed as an arbitrary unit. 
Table-1 Lipid compositions in the membranes and whole cells of $S$. elongatus.

\begin{tabular}{c|c|c|c}
\hline \multirow{2}{*}{ Component } & \multicolumn{3}{|c}{ Percentage $^{\mathrm{a})}$} \\
\cline { 2 - 4 } & $\begin{array}{c}\text { Cytoplasmic } \\
\text { membrane }\end{array}$ & $\begin{array}{c}\text { Thylakoid } \\
\text { membrane }\end{array}$ & Whole cell \\
\hline Total lipid extract & 36 & 33 & 25 \\
Pigments & 18.4 & 16.5 & 13.3 \\
Chlorophyll-a & 1.1 & 10.6 & 3.4 \\
Polar lipids & 17.6 & 16.5 & 11.8 \\
MGDGc) $^{\text {DGDG }}$ & 10.1 & 9.6 & 7.0 \\
SQDGc) $^{\text {c) }}$ & 2.9 & 2.6 & 1.5 \\
PGc) $_{\text {unidentified }}$ & 1.8 & 2.0 & 1.5 \\
& 1.4 & 1.3 & 0.5 \\
& 1.4 & 1.0 & 1.3 \\
\hline
\end{tabular}
a) Percentage of spot density on TLC, except b) which is shown as percentage by weight.
c) abbreviations : MGDG, monogalactosyldiacylglycerol ; DGDG, digalactosyldiacylglycerol ; SQDG, sulfoquinovosyldiacyl- glycerol ; and PG, phosphatidylglycerol.

and whole cells are shown in Table-1. The most remarkable difference between the membrane fractions was in the chlorophyll-a level. Contents of four classes of lipids, MGDG, DGDG, SQDG and PG, were similar between the two kinds of membranes, and essentially at a similar level to those in the CM and TM from A. nidulans ${ }^{3)}$ except relatively low content of PG in the Synechococcus membranes.

The fatty acid compositions of the lipids from the membranes and the whole cells are shown in Table-2. The predominant fatty acids in the lipids from both membranes and the whole cells were palmitic $(16: 0)$, oleic $(18: 1)$ and palmitoleic $(16: 1)$ acids. In the $\mathrm{CM}$, stearic $(18: 0)$ acid was also a major acyl moiety. The CM possessed more saturated fatty acid than the TM, though the difference of the fatty acid composition between these membranes is small. These membranes possess smaller amount of palmitoleic $(16: 1)$ acid, and larger amounts of stearic $(18: 0)$ and oleic $(18: 1)$ acids compared with the membranes from A. nidulans ${ }^{3)}$. The composition of fatty acids of this cyanobacterium is rather simple compared with those of other mesophilic and thermophilic cyanobacteria ${ }^{1), 3), 12)}$. Sat-
Table-2 Fatty acid compositions of total lipids from the membranes and whole cells of $S$. elongatus.

\begin{tabular}{c|c|c|c}
\hline \multirow{2}{*}{$\begin{array}{c}\text { Fatty } \\
\text { acid }\end{array}$} & \multicolumn{3}{|c}{ Molar percentage } \\
\cline { 2 - 4 } & $\begin{array}{c}\text { Cytoplasmic } \\
\text { membrane }\end{array}$ & $\begin{array}{c}\text { Thylakoid } \\
\text { membrane }\end{array}$ & Whole cell \\
\hline $16: 0$ & 56 & 51 & 54 \\
$16: 1$ & 12 & 17 & 13 \\
$17: 0$ & trace & trace & 1 \\
$17: 1$ & 2 & 2 & 2 \\
$18: 0$ & 11 & 5 & 8 \\
$18: 1$ & 19 & 25 & 22 \\
\hline
\end{tabular}

trace, less than $1 \%$.

urated fatty acid contents in Synechococcus membranes were $67 \%$ in the CM, $56 \%$ in the TM and $63 \%$ in the whole cells which are larger than those in the mesophilic cyanobacteria such as A. nidulans ${ }^{3)}$, Nostoc canina and Nostoc muscorum ${ }^{12}$ ) and that of the thermophilic $M$. laminosus $^{1)}$. Saturated fatty acid contents of the CM and TM from $A$. nidulans were about $50 \%$, and those of the whole cells of $N$. canina and $N$. muscorum were less than $40 \%$. The rates of saturated acids in the Mastigocladus cells grown at 40,48 and $55^{\circ} \mathrm{C}$ were 42,47 and 57 $\%$, respectively ${ }^{1)}$.

(Received Feb. 13, 1992) 


\section{References}

1) O. Hirayama and T. Kisida, Agric. Biol. Chem., 55, 781 (1991).

2) O. Hirayama and T. Inamura, Agric. Biol. Chem., 55, 1005 (1991).

3) T. Omata and N. Murata, Plant Cell Physiol., 24, 1101 (1983).

4) N. Murata and T. Omata, "Methods in Enzymol.", Vol. 167 Academic Press, San Diego (1988) p.245.

5) S. Miyairi and G.H. Shatz, Z. Naturforsch., 38 c, 44 (1983).

6) T. Yamaoka, K. Satoh, and S. Katoh, Plant Cell Physiol., 19, 943 (1978).

7) E.G. Bligh and W.J. Dyer, Can. J. Biochem. Physiol., 37, 911 (1959).

8) A.N. Siakotos and G. Rouser, J. Am. Oil Chem. Soc., 42, 913 (1965).

9) J.C. Dittmer and R.L. Lester, J. Lipid Research, 5, 126 (1964).

10) D.I. Arnon, Plant Physiol., 24, 1 (1949).

11) L.D. Metcalfe and A.A. Schmitz, Anal. Chem., 33, 363 (1961).

12) A.K. Sallal, N.A. Nimer, and S.S. Radwan, J. Gen. Microbiol., 136, 2043 (1990).
好熱性ラン藻 Synechococcus elongatus の 細胞質膜とチラコイド膜の脂質及び

\section{脂肪酸組成}

$$
\begin{gathered}
\text { 八木久彰・宮入祥夫・中原東郎・市村年昭・ } \\
\text { 松井郁夫・本田晧一 } \\
\text { 工業技術院化学技術研究所 ( } 305 \text { 茨城県つくば市東 } 1-1)
\end{gathered}
$$

好熱性ラン藻 Synechococcus elongatus から細胞質 膜とチラコイド膜を分離した。両膜の極性脂質の組成は 類似しており，モノガラクトシルジアシルグリセリンが 約 58 \%, ジガラクトシルジアシルグリセリンが約 16 \%, スルホキノボシルジアシルグリセリンが約 $11 \%$, ホ スファチジルグリセリンが約 8 \% 含まれていた。両膜 の全脂質の約 $50 \%$ は色素であり, チラコイド膜の色素 の約 $2 / 3$ はクロロフィルaであったが，細胞質膜に含ま れるクロロフィル a はわずかであった。クロロフィル以 外の色素はいずれの膜でもカロテノイドと考えられた。 両膜の脂肪酸組成も類似しており, パルミチン酸が 50 \% 以上, オレイン酸が約 $20 \%$, パルミトレイン酸が約 $15 \%$, ステアリン酸が約 $10 \%$ 含まれている。常温性の ラン藻と比較すると, Synechococcus の膜には多量の 色素が含まれており，ホスファチジルグリセリンが少な く, 脂肪酸組成が単純で, 飽和脂肪酸が多かった。

連絡者 : 宮入祥夫 